\title{
CONTACTLESS METHODS FOR QUALITY EVALUATION OF DAIRY PRODUCTS
}

\author{
Zlatin Zlatev, Miroslav Vasilev \\ Trakia University, Faculty of Technics and Technologies \\ Graf Ignatiev 38, 8602 Yambol, Bulgaria \\ e-mail: zlatin.zlatev@trakia-uni.bg,miro8611@abv.bg
}

\begin{abstract}
The aim of the report is to present a comparative analysis of the methods and technical means for assessment of the quality and safety of dairy products, particularly yellow cheese by spectral characteristics. As a result of the analysis are established appropriate methods for representation of the spectral characteristics and classification of the researched product. In the development are shown and evaluated the accuracy and performance of the results of studies conducted in the laboratory of the Trakia University, faculty of Technics and technologies with the discussed methods for evaluation the quality of the food product.
\end{abstract}

Keywords: Dairy products, Noncontact methods, Yellow cheese, Spectral analysis, Classification.

\section{INTRODUCTION}

Milk and dairy products are one of the main foods that presents on our table. Due to their structure and chemical composition they are favorable environment for microorganisms. Secondary contamination can occur in the extraction of raw materials and at different stages of production of dairy products. Today, most consumers monitor a wider range of criteria in choosing of dairy products. They consider dairy products not only in terms of their taste and their direct nutritional value, but also in terms of their potential beneficial and health effects. This makes the traditional and well-established dairy products in an appropriate basis for the search and development of new functional foods and directs its efforts towards characterization of lactic acid microflora [27,32].

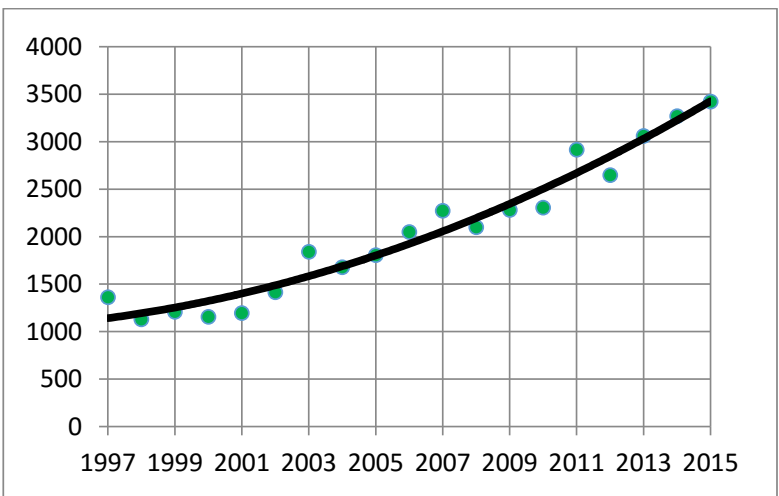

a) Keyword „Cheese“

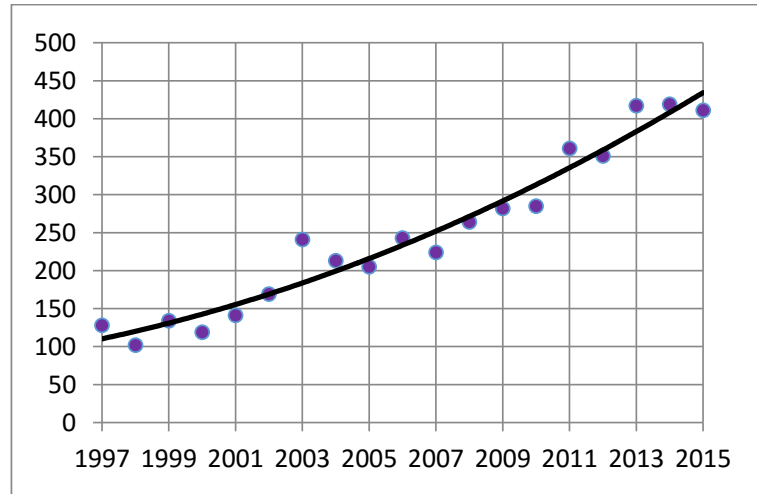

b) Keyword „Yellow cheese“

Figure 1. Number of publications for dairy products in Google Scholar and ScienceDirect

IRTIIE Vol. 4, No. 1, 2016 ISSN 1314-8788 (print), ISSN 1314-8796 (online), doi: 10.15547/artte.2016.01.005 


\section{ARTTE $Y$}

Ipplied Researirthes in Technics, Technologies ind Eduration

Journal of the Faculty of Technics and Technologies, Trakia University https://sites.google.com/a/trakia-uni.bg/artte/

Therefore, before, now and in the future dairy products have been, are and will be a constant subject of research by many scientists. This is evidenced the recent upward trend in the number of scientific papers published in refereed databases [9,24] „ScienceDirect" and "Google Scholar" (Figure 1) on the innovations in assessing the quality of dairy products.

With the country's accession to the European Union (EU) dairy industry has become an integrated part of the European Common Market, as well as to policy and regulations existing in the market and on market competition. The milk sector in Bulgaria, unlike that of other member states, has its specificity - it is based mainly on cattle, although Bulgaria has traditionally been a manufacturer and sheep, goat and buffalo milk - in the limited quantities. While in other EU countries the share of cow's milk is over $98 \%$, in Bulgaria it is between $85-$ $90 \%$ with an expected upward trend due to the continued contraction of the sheep and goat farming in the new marginalization [4].

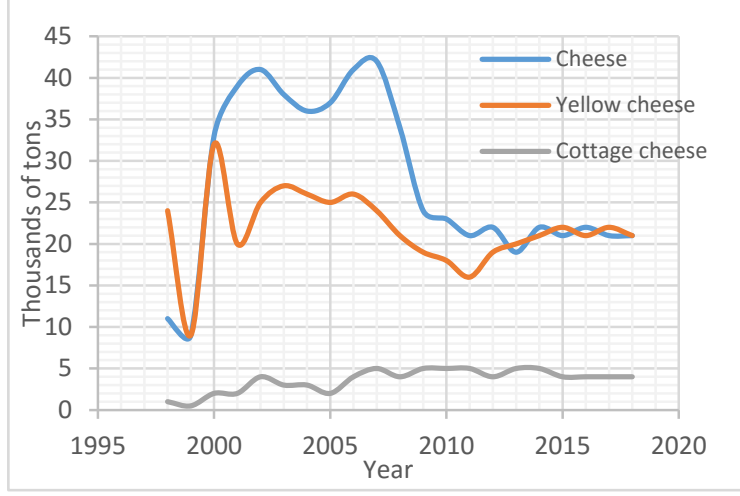

a) Production of dairy products

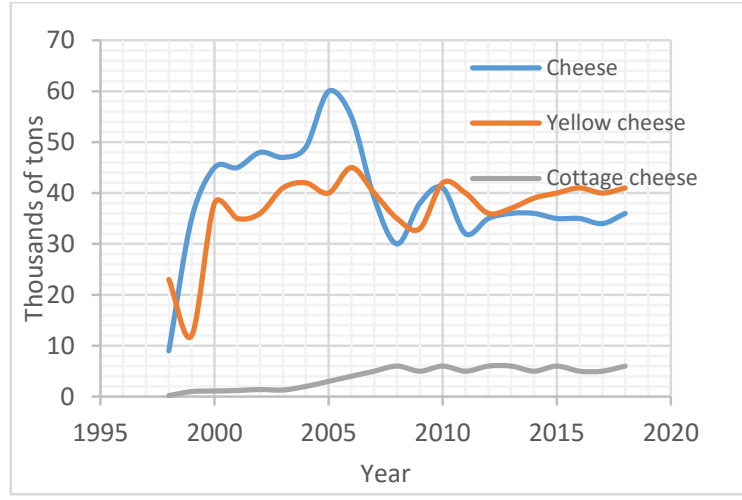

b) Consumption of dairy products

Figure 2. Production and consumption of dairy products by year

The results of in-depth analysis testify to a distinct tendency to maintain high levels of production and consumption (Figure 2) dairy products from cow's milk in Bulgaria and the European Union, White and Yellow Cheese remains one of the most consumed products [8]. The production and control of this product should be harmonized with European requirements and tailored to the nature and specifics of consumer needs. Safety, quality and wholesomeness of dairy products can only be guaranteed through the integration of law and control the entire food chain. The achieving of these indicators on food also is a goal that requires joint efforts and competence of experts from various professional fields technologists, engineers. Standards related to the quality and safety of dairy products are subject to improvement by amendments - adopted procedures for standardization in practice, if some of their clauses and details do not withstand the test of time.

International Standard BDS EN ISO 22000 integrates the principles of the system of hazard analysis and critical control points (HACCP - Hazard Analysis and Critical Control Points) with: ISO 22004 for steps for its implementation, developed by the Commission of Codex Alimentarius; BDS EN ISO 22005 - Traceability in the food and food chain ISO/TS 22003 management systems of food safety. The national standard for Bulgarian yellow cheese BDS 14: 2010 is valid from 16.11.2010 and applies to Bulgarian yellow cheese made from cow, sheep or mixed milk, whole or in standardized ratio casein / fat using starter culture produced in Bulgaria selected strains of lactic acid bacteria isolated in Bulgaria by coagulation with rennet, given the necessary treatment, undergo a process of ripening and intended for consumption.

IRTTIE Vol. 4, No. 1, 2016 ISSN 1314-8788 (print), ISSN 1314-8796 (online), doi: 10.15547/artte.2016.01.005 


\section{IRTTIE}

Ipplied Researleches in Technics, Technologies and Bdurotion

Journal of the Faculty of Technics and Technologies, Trakia University https://sites.google.com/a/trakia-uni.bg/artte/

\section{NONDESTRUCTIVE METHODS FOR OBJECTIVE ASSESSMENT OF THE QUALITY OF DAIRY PRODUCTS}

In recent years are carried research for dairy products to determine the brand (manufacturer) of white and yellow cheese, identification of the content of hydrogen peroxide, the geographical origin of the product. In modern stage are seek methods for coadministration of multi-sensor systems with or without fusing the data from them for quality evaluation of dairy products [14]. In Table 1 are presented from the literature known types of sensors and measurement methods used in assessing the quality of dairy products. Some of the methods are contact, while others are used without a direct physical impact on the product.

Table 1. Sensors used for analysis and evaluation of the quality of dairy products

\begin{tabular}{|c|c|c|c|}
\hline $\begin{array}{l}\text { Type of the } \\
\text { sensor }\end{array}$ & $\begin{array}{c}\text { Method of } \\
\text { measurement }\end{array}$ & Description & Reference \\
\hline $\begin{array}{l}\text { Conductive } \\
\text { electrode }\end{array}$ & Conductance & The method is contact & {$[15,20]$} \\
\hline Gas & Resistance, frequency & $\begin{array}{l}\text { Electronic nose - contactless method used } \\
\text { are polymer or resistive sensing elements }\end{array}$ & \multirow{2}{*}[21,31]{} \\
\hline Biosensors & Resistance, frequency & $\begin{array}{l}\text { Electronic tongue - contact method used are } \\
\text { selective sensors }\end{array}$ & \\
\hline $\mathrm{pH}$ & Acidity & pH meter - contact method & {$[27,30,31]$} \\
\hline Viscosity & $\begin{array}{l}\text { Current of the motor, } \\
\text { time to expiration }\end{array}$ & Viscometer - contact method & [27] \\
\hline Penetration & Penetrometer & $\begin{array}{l}\text { Contact method - measuring the force } \\
\text { required for penetrating of the sensitive } \\
\text { element in the product }\end{array}$ & [22] \\
\hline Optical & $\begin{array}{l}\text { NIR, VIS, UV, IR, } \\
\text { laser }\end{array}$ & $\begin{array}{l}\text { Spectrometers, colorimeters with transition } \\
\text { and reflection, video camera }\end{array}$ & {$[7,12,21]$} \\
\hline Ultrasound & $\begin{array}{l}\text { Impedance, } \\
\text { amplitude, frequency }\end{array}$ & Non-contact method - reflection or transition & [1] \\
\hline
\end{tabular}

Table 2. Comparative analysis of optical methods for non-destructive evaluation of the quality of dairy products

\begin{tabular}{|c|c|c|c|}
\hline Method & Advantages & Disadvantages & Reference \\
\hline \multirow{3}{*}{ Computed tomography } & Non-destructive & High cost of the equipment & \multirow{3}{*}{ [16] } \\
\hline & \multirow{2}{*}{$\begin{array}{l}\text { Detailed images are } \\
\text { obtained }\end{array}$} & Long time for data processing & \\
\hline & & Limitation of application areas & \\
\hline \multirow{3}{*}{ Computer vision } & $\begin{array}{l}\text { Can be obtained spatial } \\
\text { information about the } \\
\text { object }\end{array}$ & $\begin{array}{l}\text { Restriction for objects with varied } \\
\text { composition }\end{array}$ & \multirow{3}{*}{ [33] } \\
\hline & $\begin{array}{l}\text { Higher precision than the } \\
\text { human judgment }\end{array}$ & \multirow{2}{*}{$\begin{array}{l}\text { Not suitable for detection of the internal } \\
\text { defects }\end{array}$} & \\
\hline & $\begin{array}{l}\text { The ability to detect } \\
\text { external defects }\end{array}$ & & \\
\hline \multirow{3}{*}{ Spectral analysis } & Easy to use & \multirow{3}{*}{$\begin{array}{l}\text { Limited sensitivity to small changes in the } \\
\text { properties of the object }\end{array}$} & \multirow{3}{*}{ [6] } \\
\hline & $\begin{array}{l}\text { Obtaining of spectral } \\
\text { information }\end{array}$ & & \\
\hline & $\begin{array}{l}\text { Suitable for internal } \\
\text { defects }\end{array}$ & & \\
\hline \multirow{3}{*}{ Hyperspectral analysis } & $\begin{array}{l}\text { Obtaining of spectral and } \\
\text { spatial information }\end{array}$ & Висока цена на оборудването & \multirow{3}{*}{ [11] } \\
\hline & $\begin{array}{l}\text { High sensitivity to small } \\
\text { changes in object }\end{array}$ & \multirow[b]{2}{*}{ Problems processing the data } & \\
\hline & $\begin{array}{l}\text { Construction of images } \\
\text { on the chemical } \\
\text { composition of the object }\end{array}$ & & \\
\hline
\end{tabular}

IIITTE Vol. 4, No. 1, 2016 ISSN 1314-8788 (print), ISSN 1314-8796 (online), doi: 10.15547/artte.2016.01.005 
Contact methods have significant disadvantage that measured on immersion of the measuring probe in the product, in which can be inserted micro-organisms from the environment. For example, some types of electronic tongues use sensors that measure the extent of the chemical reaction between the chemical substance and product to detect the presence of harmful toxic element for humans [13]. These disadvantages of the contact methods of measurement are prerequisites for seeking suitable contactless methods for assessing key quality indicators of dairy products. Such techniques are optical, gas, ultrasound. Gas sensors are suitable for assessment of raw milk as a feedstock for the production of dairy products. For example, in lactic acid fermentation of Bulgarian yoghurt does not emit odoriferous substances and this type of sensors are not appropriate. They could be applied in the preparation of functional foods from milk as yogurt, cheese, cottage cheese, because it is possible products used as additives to emit aromatic substances in fermenting. Video sensors are suitable mainly for assessment of milk and again in the preparation of functional foods and microbiological analysis in microscopic research and evaluation of surface characteristics of dairy products.

Table 3. Examples of application of spectral analysis for quality assessment of dairy products

\begin{tabular}{|c|c|c|c|c|c|c|}
\hline $\begin{array}{l}\text { Spectral } \\
\text { range, } \mathrm{nm}\end{array}$ & $\begin{array}{l}\text { Parameters of the } \\
\text { product }\end{array}$ & $\begin{array}{l}\text { Number } \\
\text { of the } \\
\text { samples }\end{array}$ & $\begin{array}{l}\text { Method of } \\
\text { representing of the } \\
\text { data }\end{array}$ & Method for processing & Reported results & Ref. \\
\hline $\begin{array}{l}270 \div 550 \\
310 \div 590\end{array}$ & Riboflavin & 42 & $\begin{array}{l}\text { Parallel factor } \\
\text { analysis } \\
\text { (PARAFAC) }\end{array}$ & $\begin{array}{l}\text { Partial least squares } \\
\text { regression (PLSR) }\end{array}$ & $R^{2}=0,94 \div 0,97$ & [36] \\
\hline $\begin{array}{l}400 \div 1000 \\
325 \div 1075\end{array}$ & $\begin{array}{l}\text { Determination the } \\
\text { type of product }\end{array}$ & 160 & $\begin{array}{c}\text { Principal } \\
\text { component } \\
\text { analysis (PCA) }\end{array}$ & $\begin{array}{l}\text { Back propagation } \\
\text { Neural network } \\
\text { (BPN) }\end{array}$ & $100 \%$ recognition & [37] \\
\hline No data & $\begin{array}{l}\text { Determination of } \\
\text { arsenic, plumbum, } \\
\text { mercury and } \\
\text { selenium }\end{array}$ & No data & $\begin{array}{l}\text { Comparative } \\
\text { analysis of five } \\
\text { measuring } \\
\text { apparatus }\end{array}$ & $\begin{array}{l}\text { Relationship with } \\
\text { reference } \\
\text { parameters }\end{array}$ & $\begin{array}{c}\text { Common error of } \\
\text { the devices } \\
0 \div 23 \%\end{array}$ & [19] \\
\hline $325 \div 1075$ & Sugar and $\mathrm{pH}$ & 35 & $\begin{array}{l}\text { Combination of } \\
\text { PCA and artificial } \\
\text { neuron network } \\
\text { (ANN) }\end{array}$ & PLSR & $R^{2}=0,91 \div 0,92$ & [26] \\
\hline $200 \div 1000$ & $\begin{array}{l}\text { Amendment } \\
\text { during storage of } \\
\text { the humidity, } \\
\text { protein, fat, ash } \\
\text { content }\end{array}$ & No data & $\begin{array}{l}\text { Conversion of } \\
\text { spectrum to L, S, H } \\
\text { color components }\end{array}$ & $\begin{array}{c}\text { Analysis of variance } \\
\text { (ANOVA) }\end{array}$ & $\begin{array}{c}\text { Non-parametric } \\
\text { comparative } \\
\text { analysis }\end{array}$ & [28] \\
\hline $500 \div 2500$ & $\begin{array}{l}\text { Determination the } \\
\text { type of product }\end{array}$ & No data & \multicolumn{2}{|c|}{$\begin{array}{l}\text { Possibilities for predicting parameters by } \\
\text { spectral characteristics }\end{array}$} & $\begin{array}{c}\text { Non-parametric } \\
\text { comparative } \\
\text { analysis } \\
\end{array}$ & [18] \\
\hline $1100 \div 2300$ & Fat content & 141 & $\begin{array}{c}\text { Coefficients of } \\
\text { PLSR }\end{array}$ & PLSR & $R^{2}=0,93 \div 0,98$ & [10] \\
\hline $200 \div 1000$ & $\begin{array}{l}\text { Changes during } \\
\text { storage: } \mathrm{pH}, \\
\text { viscosity }\end{array}$ & 75 & $\begin{array}{l}\text { Coefficients of } \\
\text { PLSR and } \\
\text { relationship with } \\
\text { reference } \\
\text { parameters }\end{array}$ & PLSR & $\begin{array}{c}\mathrm{R}^{2}=0,02 \div 0,85 \\
\text { depending on the } \\
\text { observed } \\
\text { parameters }\end{array}$ & [2] \\
\hline $400 \div 1200$ & Protein & 257 & $\begin{array}{l}\text { Coefficients of } \\
\text { PLSR }\end{array}$ & OC-PLS (one class) & $10 \%$ outliers & [35] \\
\hline $1000 \div 4000$ & Melamine & No data & No data & Correlation analysis & $\begin{array}{c}2 \% \text { precision of } \\
\text { determination }\end{array}$ & [23] \\
\hline $900 \div 1700$ & Fat content & No data & $\begin{array}{l}\text { Coefficients of } \\
\text { PLSR }\end{array}$ & PLSR & $R^{2}=0,97$ & [25] \\
\hline $\begin{array}{l}420,520 \\
\quad 700\end{array}$ & $\begin{array}{l}\text { Changing of the } \\
\text { pigments during } \\
\text { storage }\end{array}$ & No data & $\begin{array}{l}\text { Conversion of } \\
\text { spectrum to color } \\
\text { components }\end{array}$ & No data & $\begin{array}{c}\text { Non-parametric } \\
\text { comparative } \\
\text { analysis }\end{array}$ & [34] \\
\hline
\end{tabular}

IRTIIE Vol. 4, No. 1, 2016 ISSN 1314-8788 (print), ISSN 1314-8796 (online), doi: 10.15547/artte.2016.01.005 


\section{IRTTL}

Ipplied Resseirlches in Technics, Technologies and Bductation

Journal of the Faculty of Technics and Technologies, Trakia University https://sites.google.com/a/trakia-uni.bg/artte/

More universal application than other methods are found optical and ultrasonic sensors that are applied to assess the quality of dairy products at all stages of production and that acceptance of raw milk pasteurization, starter culture, tracking of the fermentation process, control of final product and storage. Known from the literature for non-destructive analysis of dairy products occupy considerable space the optical methods. Such methods are computer vision, spectral and hyperspectral analysis. Table 2 presents comparative analysis of the presented methods for non-destructive evaluation of the quality of meat and meat products and are listed their advantages and disadvantages.

The spectral analysis is a set of physical methods for quantitatively and qualitatively determining the composition of substances by studying their spectra. It is widely used in the research of the quality of various food products, including milk and dairy products. Compared with computer vision, spectral analysis has found wider application in assessing the quality of dairy products. The possibilities for application of spectral analysis in the near infrared and mid-infrared range are well studied in the evaluation of dairy products. This includes monitoring the production process, determining the geographical origin, quality assessment, monitoring the ripening process of some dairy products. The relationship between the composition of a substance is the electromagnetic spectrum emitted or absorbed by it, allows spectral analysis be used as sensitive, relatively simple and quick method in research and industry. One of its advantages is that it can be applied to a large number of samples without this having a significant impact on the price and timing of the study $[13,32]$.

\section{METHODS OF EXTRACTING THE INTRINSIC PROPERTIES OF SPECTRAL CHARACTERISTICS}

Principal component analysis (PCA) [26]. Extracting characteristic features is a transformation of the original data with all their variables in a sample of reduced benefits. Use all measurements or variables that are designed in small size area. The reasons for the extraction of characteristic properties are as follows:

$>$ Reducing the bandwidth of the input data;

$>$ Providing a smaller number of features to speed up the classification;

$>$ To reduce the surplus of information;

$>$ To obtain a smaller dimension of the data in the ideal case - two dimensions with a minimum loss of information and in this way data are displayed better.

Discrete parametric models [3]. Discrete parametric models reflect discrete behavior of the object only in moments of time that are multiples of the so-called "time sampling" - time measurement clock cycle $T_{0}$. For processing of the spectral characteristics of the surface areas of dairy products are selected discrete parametric models as they are discreet in nature.

\section{METHODS FOR PROCESSING OF SPECTRAL DATA AND CLASSIFICATION}

In the study are used methods for classification: discriminant analysis DA; K-nearest neighbors KNN; Method of support vector machines SVM (Figure 3). Referred are the main characteristics of these methods.

IRTIIE Vol. 4, No. 1, 2016 ISSN 1314-8788 (print), ISSN 1314-8796 (online), doi: 10.15547/artte.2016.01.005 


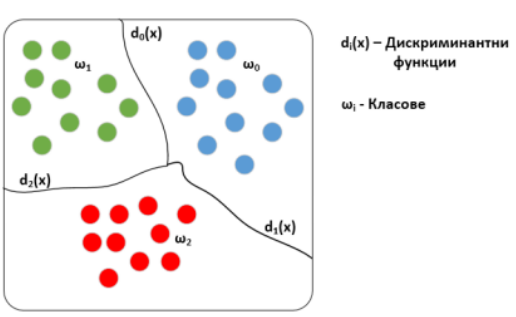

a) DA

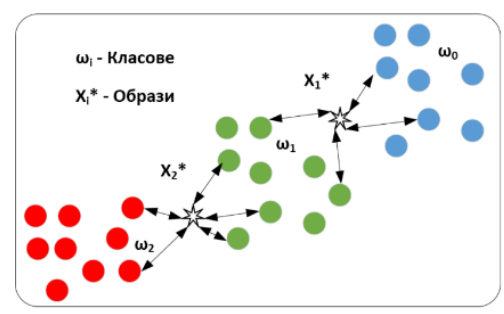

b) KNN

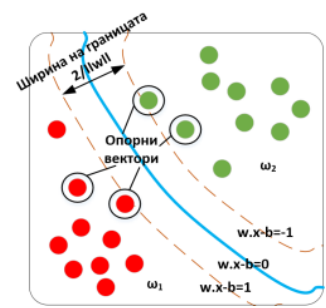

c) SVM

Figure 3. Methods for classification used in the investigation

Discriminant analysis [5,13]. The discriminant analysis is multidimensional data analysis, which is used when there is need for "predicting" the values of the grouping variable. This is also called classification or pattern recognition. In non-linear discriminant analysis to build non-linear discriminant functions of the predictors. The aim is to obtain a rule for assignment of a new observation of the given class. Assignment or "distribution" to a certain class of features is necessary on this development.

K-Nearest Neighbors (KNN) [13]. The method of k-nearest neighbor (k-nearest neighbors method- KNN) is a method of classification of images, which is based on the closest training examples in the space of features. Unknown image refers to a class to which they belong at least $S$ from $k$ nearest neighbors by providing a sample of images. $S$ is the threshold for credibility.

Support vector machines (SVM) [17,29]. In this method is performed non-linear transformation of the original data in another space with a higher dimension where the objects are linearly separable (Figure 6c). In SVM - the method on the support points that represent breakpoints for a class data in multidimensional space of the features can be calculated hyper planes separating classes for which the distance limits between the two classes is maximum.

The original algorithm of the SVM method is linear, but are developed and nonlinear ones. In nonlinear algorithm data are separated by a non-linear kernel function. This allows the algorithm to match the hyper plane with the greatest separation between the two classes in the transformed feature space. The kernel non-linear function can be homogeneous polynomial, non-homogeneous polynomial, Gaussian radial basic and hyperbolic. The significance of the parameter Capacity - C, which is common to all types of SVM, account during the phase of training of the classifier and is expressed in prioritizing one of the two factors - minimizing the number of wrongly classified objects of the training sample or complexity factors of the synthesized hyper plane.

Erross in determining the parameters of the models are calculated by equations, described in table 4.

Two-factor analysis of variance [28]. The main objective of the analysis of variance is as in regression analysis - to investigate the significance of a particular group of factors (independent variables) on a dependent variable, but here factors are nominal variables. Two-way analysis of variance allows simultaneously to study the influence of two factors on the outcome of the research object.

Partial least squares regression and principal component regression [25,26]. Quantitative analysis of the data was realized by partial least squares regression (PLSR) and principal component regression (PCR). The effectiveness of certain methods in the processing of predictive values with high dimension, such as the spectral characteristics of meat and sausages. Both methods generate new predictive variables known as components as a linear combination of the original predictive values. Methods used to analyze data

IRTIIE Vol. 4, No. 1, 2016 ISSN 1314-8788 (print), ISSN 1314-8796 (online), doi: 10.15547/artte.2016.01.005 


\section{IRTITE

create these components differently. PCR creates components describing the variation in the prediction variables without considering basic components. In the partial least squares regression these output variables are taken into consideration and results obtained with lower accuracy at a small number of components. The choice of method of analysis of the data depends upon the particular application in which they are used.

Table 4. Errors in determining the parameters of the models

\begin{tabular}{|c|c|c|}
\hline $\mathrm{R}^{2}$ & $R^{2}=\frac{r_{s s}}{t_{s s}} \quad \begin{array}{c}t_{s s}=\sum_{i=1}^{n}\left(y_{i}-y_{\text {mean }}\right)^{2} \\
r_{s s}=\sum_{i=1}^{n}\left(y_{i}-y_{i f i t}\right)^{2}\end{array}$ & $\begin{array}{l}R^{2}-\text { Regression coefficient } \\
y_{i}-\text { Measured values } \\
y_{\text {mean }}-\text { Mean of measured values } \\
y_{f i t}-\text { Values of the model } \\
n-\text { Number of measurements }\end{array}$ \\
\hline MSE & $M S E=\frac{1}{n} \sum_{i=1}^{n}\left(y_{i \text { pred }}-y_{i}\right)^{2}$ & $\begin{array}{l}\text { MSE - Mean squared error } \\
y_{i \text { pred }} \text { - Predicted values } \\
y_{i}-\text { Measured values } \\
n-\text { Number of measurements }\end{array}$ \\
\hline RMSE & $R M S E=\sqrt{\frac{1}{n} \sum_{i=1}^{n}\left(y_{i \text { pred }}-y_{i}\right)^{2}}$ & $\begin{array}{l}\text { RMSE - Root mean squared error } \\
y_{i} \text { pred }- \text { Predicted values } \\
y_{i}-\text { Measured values } \\
n-\text { Number of measurements }\end{array}$ \\
\hline 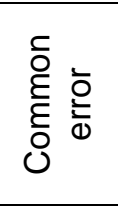 & $\varepsilon_{0}=\frac{\sum_{i=1}^{n}\left(\sum_{k=1}^{n} y_{i k}-y_{i i}\right)}{\sum_{i=1}^{n} \sum_{k=1}^{n} y_{i k}} .100, \%$ & $\begin{array}{l}y_{i k} \text { is number of samples from class } i \text {, classified in class } k \\
y_{i i}-\text { Number of correctly recognized samples } \\
k=1 \ldots n-\text { number of incorrectly classified as a class } i \text { in } \\
\text { the total number of samples } \\
n-\text { Number of classes }\end{array}$ \\
\hline
\end{tabular}

\section{ANALYSIS AND ASSESSMENT OF THE CHANGE OF SURFACE CHARACTERISTICS OF DAIRY PRODUCTS BY SPECTRAL DATA}

Objects of the study is yellow cheese purchased from a licensed manufacturer and manufactured of BDS and the adjacent regulations. Characteristics to be assessed are surface changes of the product in storage in conditions not complying with the requirements specified by the manufacturer. The spectral characteristics were obtained with laboratory staging for measuring spectral characteristics of reflection in the visible spectral region, developed at the Department of „Electronics, Electrical Engineering and Automation” of the faculty "Technics and Technology" - Yambol. Laboratory measurements of titratable acidity were made at the Department of "Food Technologies" at the same faculty. Figure 4 shows the spectral characteristics of object areas with yellow cheese and mold during every day of measurement. There is overlap of these characteristics in different spectral ranges are also visible differences in these characteristics, for example in the range $550 \div 600 \mathrm{~nm}$.

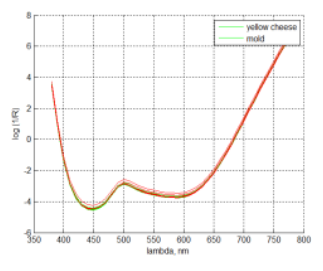

a) day 1

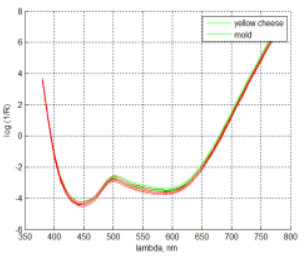

b) day 3

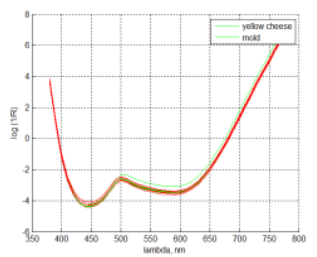

c) day 4

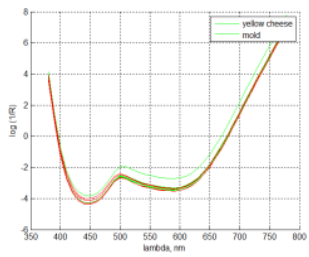

d) day 6

Figure 4. Spectral characteristics of object areas with yellow cheese and mold in different days of measurement

IRTIIE Vol. 4, No. 1, 2016 ISSN 1314-8788 (print), ISSN 1314-8796 (online), doi: 10.15547/artte.2016.01.005 


\section{$>$ Presentation of the spectral characteristics as features}

Figure 5 shows auto regression coefficients and major components of the measured spectral characteristics of the yellow cheese and mold on day 3 . There is a partial overlap of the autoregression coefficients, while the principal components is available clearly distinguish of the surface characteristics of product under study, divided into two classes "yellow cheese" and "mold".

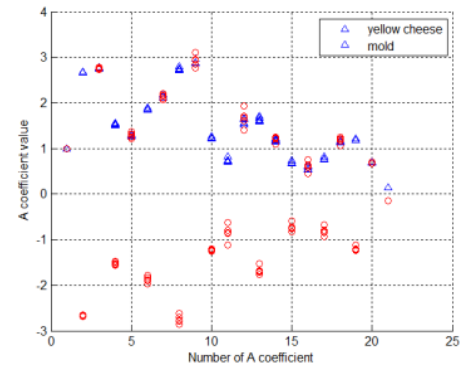

a) $A R$

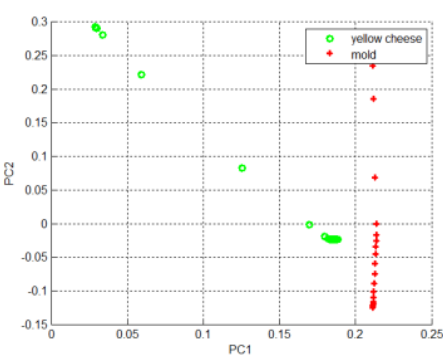

b) $\mathrm{PC}$

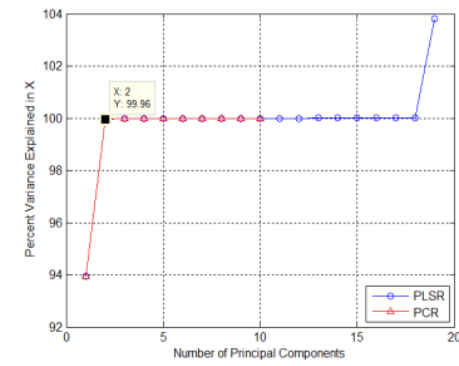

c) Number of PCs

Figure 5. Representation of the spectral characteristics as features for day 3

\section{$>$ Designation of the necessary number of principal components for a description of spectral characteristics}

Figure $5 \mathrm{c}$ presents the results in determining the required number of major components for a description of spectral characteristics of the object areas with yellow cheese and mold. It can be seen that the two main components describing $99,9 \%$ of the variance in the data.

\section{> Evaluation of the separability of object areas of spectral characteristics in different days of storage by classifiers}

The evaluation of the separability of object areas was realized with three classifiers that are most commonly used for analysis of dairy products. These are discriminant analysis (DA), method of support vector machines (SVM) method and K-Nearest Neighbors (KNN). DA and SVM are used with nonlinear separating functions.

Discriminant analysis. Figure 7 shows the results when using a non-linear discriminant analysis of separability of the object areas with yellow cheese and mold on day 3 .

For all days of storage were used spectral characteristics (raw), Autoregression coefficients (AR) and principal components (PC). For all methods of data representation is observed overlapping of classes.

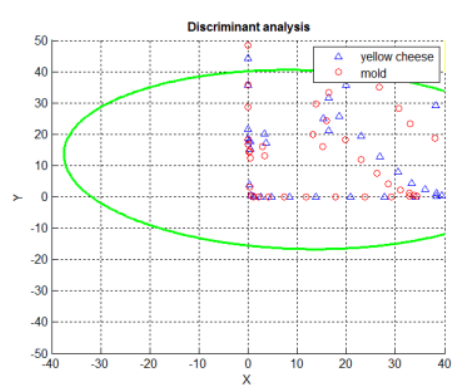

Raw

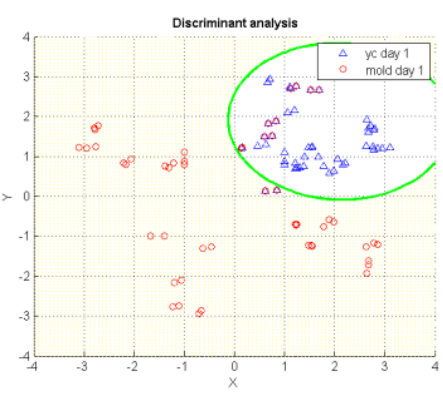

AR

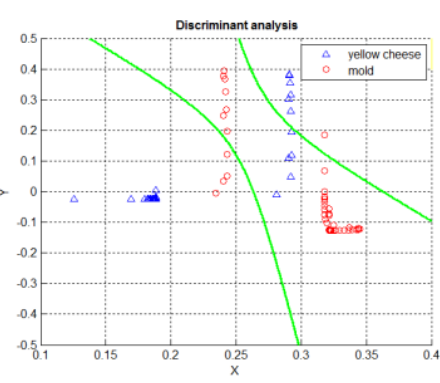

PC

Figure 7. Classification with DA for day 3

IRTIIE Vol. 4, No. 1, 2016 ISSN 1314-8788 (print), ISSN 1314-8796 (online), doi: 10.15547/artte.2016.01.005 
Table 5. Separability of object areas on a particular day of the storage with discriminant analysis

\begin{tabular}{|c|c|c|c|}
\hline \multirow{2}{*}{ Day of the storage } & Raw & AR & PC \\
\cline { 2 - 4 } & $\varepsilon_{0}, \%$ & $\varepsilon_{0}, \%$ & $\varepsilon_{0}, \%$ \\
\hline day 1 & 49 & 11 & 1 \\
\hline day 3 & 47 & 11 & 5 \\
\hline day 4 & 46 & 12 & 4 \\
\hline day 6 & 46 & 12 & 9 \\
\hline Raw - spectral characteristics; AR - auto regression coefficients; PC - principal components \\
\hline
\end{tabular}

This overlap is also reflected by the common error of the classification. The values of this error for all days of storage are presented in Table 5. Small amounts of the common error is obtained using major components $\varepsilon_{0}=1 \div 9 \%$. Using a nonlinear discriminant analysis and two other classifiers for the presentation of object areas - spectral characteristics and autoregression coefficients the common error greatly exceeding $10 \%$.

KNN analysis. The results of Severability of object areas for day 3 are shown in Figure 8. Overlap between the two classes is observed using direct spectral characteristics and Autoregression coefficients while using the principal components will overlap of classes on this day.

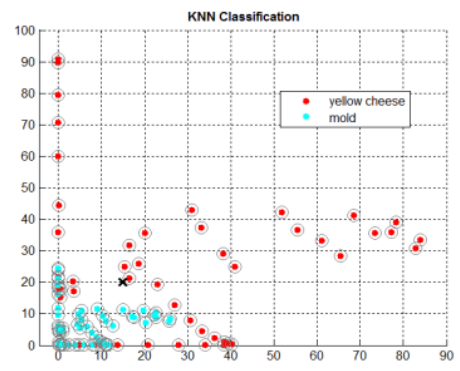

Raw

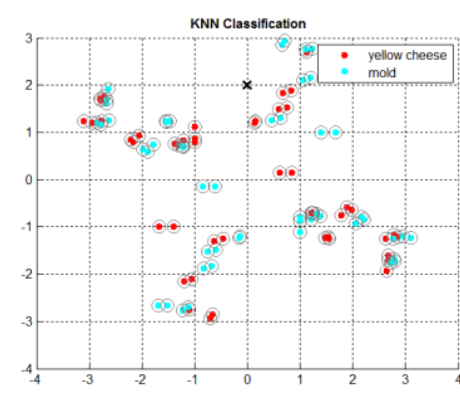

AR

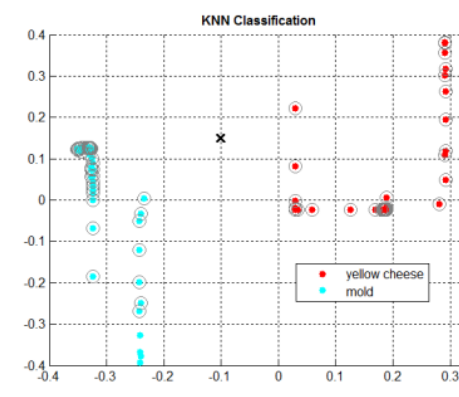

PC

Figure 8. Classification with KNN for day 3

Table 6. Separability of object areas on a particular day of the storage with KNN analysis

\begin{tabular}{|c|c|c|c|}
\hline \multirow{2}{*}{ Day of the storage } & Raw & AR & PC \\
\cline { 2 - 4 } & $\varepsilon_{0}, \%$ & $\varepsilon_{0}, \%$ & $\varepsilon_{0}, \%$ \\
\hline day 1 & 30 & 25 & 5 \\
\hline day 3 & 26 & 31 & 13 \\
\hline day 4 & 28 & 32 & 12 \\
\hline day 6 & 34 & 19 & 3 \\
\hline Raw - spectral characteristics; AR - auto regression coefficients; PC - principal components
\end{tabular}

This trend is observed for the remaining days of storage. Table 6 indicates the values of the common error in classification by three methods for presenting data of object areas with yellow cheese and mold. Using principal components was observed common error within $3 \div 13 \%$ depending on the day of measurement. In other methods of representing the spectral characteristics the common error is over $10 \%$.

SVM analysis. Figure 9 shows the results in the classification of yellow cheese for day 3 of storage. The processing of data by the three methods for their submission with the method of the support vectors indicates that the direct use of spectral characteristicsoverlapping was observed of the two classes while using the autoregressive coefficients, and the main components that overlap is with minimal error.

IRTIIE Vol. 4, No. 1, 2016 ISSN 1314-8788 (print), ISSN 1314-8796 (online), doi: 10.15547/artte.2016.01.005 


\section{IRTITE}

Ipplied Resererches in Technics, Technologies and Bduration Journal of the Faculty of Technics and Technologies, Trakia University https://sites.google.com/a/trakia-uni.bg/artte/

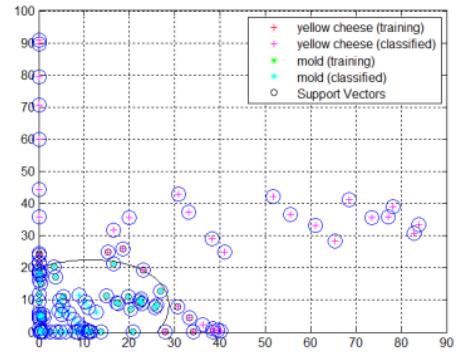

Raw

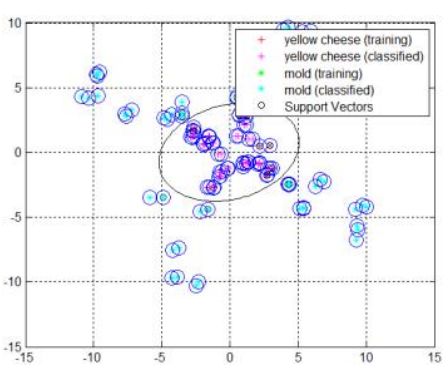

AR

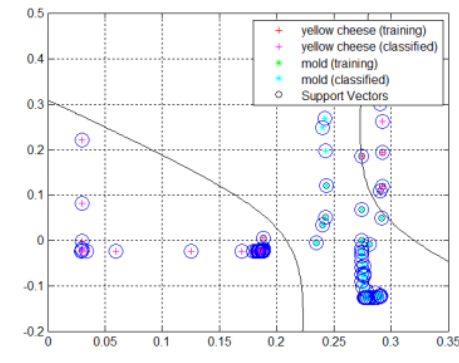

PC

Figure 9. Classification with SVM for day 3

Table 7. Separability of object areas on a particular day of the storage with SVM analysis

\begin{tabular}{|c|c|c|c|}
\hline \multirow{2}{*}{ Day of the storage } & Raw & AR & PC \\
\cline { 2 - 4 } & $\varepsilon_{0}, \%$ & $\varepsilon_{0}, \%$ & $\varepsilon_{0}, \%$ \\
\hline day 1 & 35 & 2 & 2 \\
\hline day 3 & 31 & 2 & 4 \\
\hline day 4 & 36 & 2 & 4 \\
\hline day 6 & 31 & 2 & 2 \\
\hline Raw - spectral characteristics; AR - auto regression coefficients; PC - principal components \\
\hline
\end{tabular}

Evidence of this is the common error of the overlap of classes for individual days of measurements, which values are presented in Table 7. Using auto regression coefficients and principal components error values are between $2 \div 4 \%$, while in the direct use of spectral characteristics the common error is over $10 \%$.

Results from analysis of the processing time. The values for the time of data processing in classification are coefficient of variation $3 \div 12 \%<<30 \%$, so it can be presented as mean values (Figure 10). Data on time for the processing at classification are analyzed with twoway analysis of variance by the means of Data Analysis Toolpack of MS Excel. At accuracy level $\alpha=0,05$ the results obtained are presented in Table 8 . The table shows that it is derived significance level $p<0,05$, which indicates that there are differences in the results using the various classifiers and other methods of representing data. The results of the analysis indicate that at least processing time is obtained with direct using of the spectral characteristics and classification method of K-Nearest Neighbors (KNN).

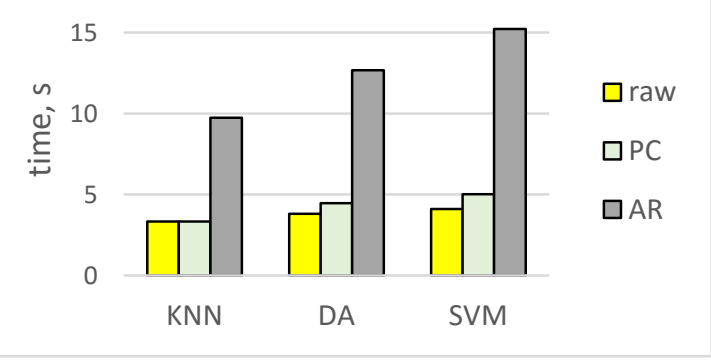

a) depending on the classifier

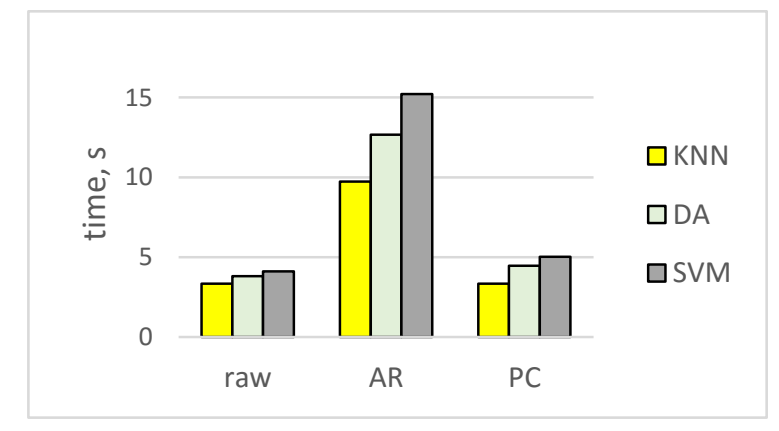

b) depending on the features

Figure 10. Time for processing the results of classification

IRTIIE Vol. 4, No. 1, 2016 ISSN 1314-8788 (print), ISSN 1314-8796 (online), doi: 10.15547/artte.2016.01.005 
Table 8. Analysis of the results of time for data classification

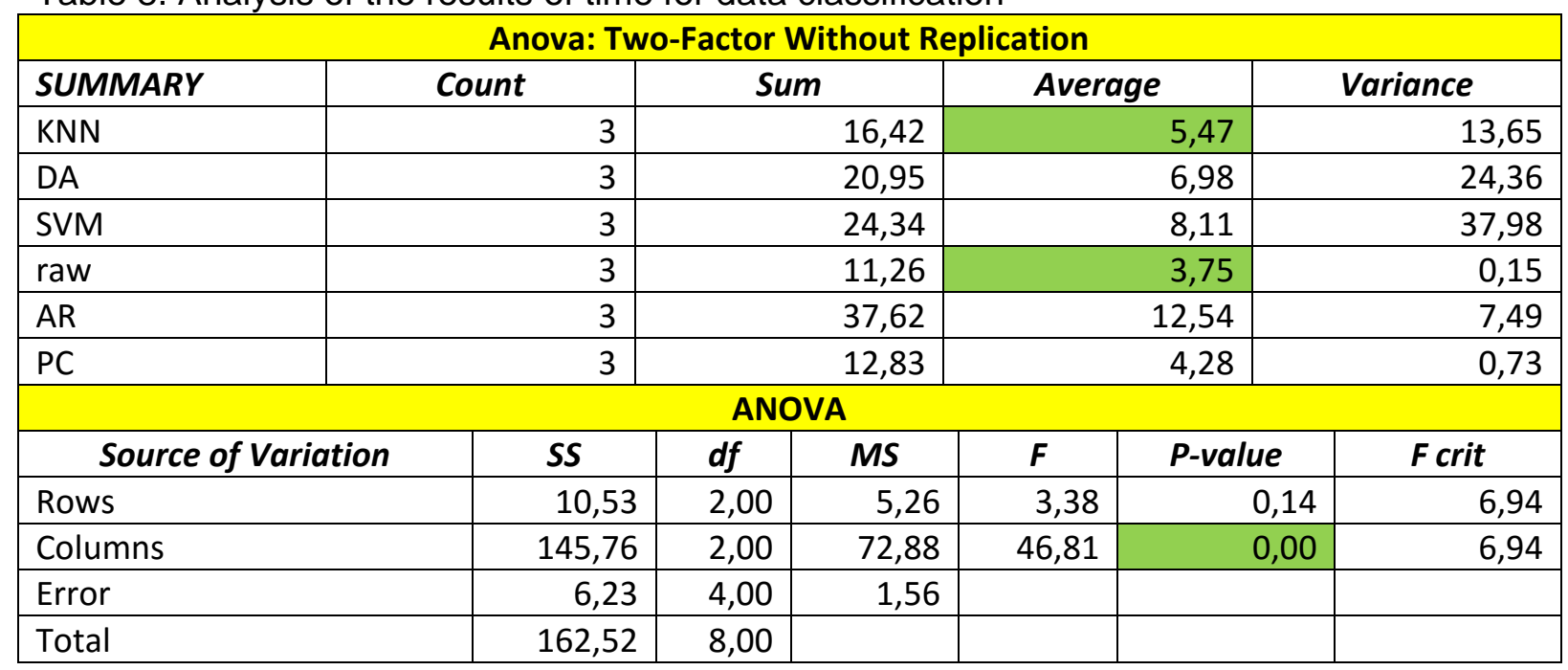

Errors in the classification. Errors in the classification are coefficient of variation $3 \div 12 \%$ $<30 \%$ so it can be presented as mean values (Figure 11). Data on time for the processing at classification are analyzed with two-way analysis of variance by the means of Data Analysis Toolpack of MS Excel. At accuracy level $\alpha=0,05$ the results obtained are presented in Table 9. The table shows that it is derived significance level $p<0,05$, which indicates that there are differences in the results using the various classifiers and other methods of representing data. The results of the analysis indicate that the smallest value of common error is obtained with using of principal components and classification method of support vector machines (SVM).

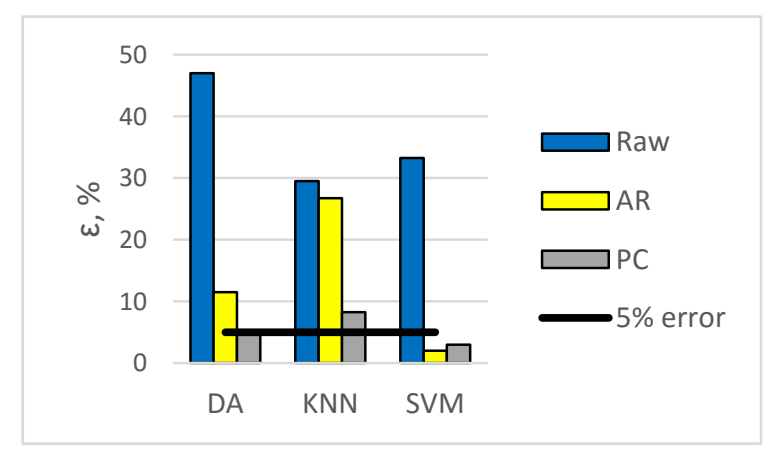

a) depending on the classifier

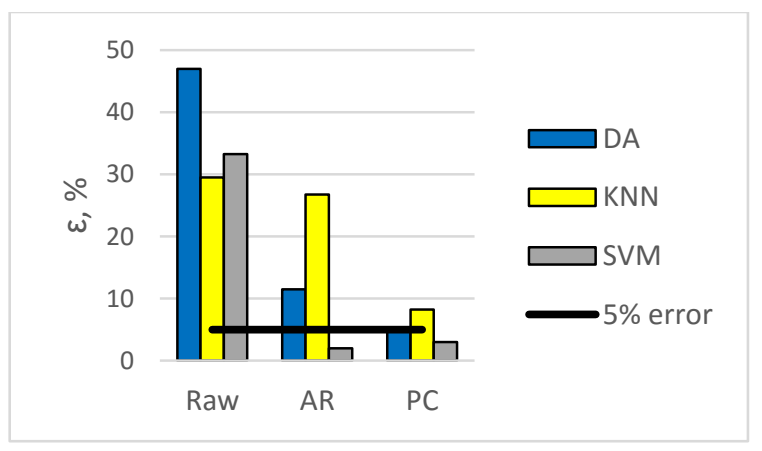

b) depending on the features

Figure 11. Common error of classification

Predicting the titratable acidity by partial least squares regression. Figure $12 \mathrm{a}$ presents the results of prediction of titratable acidity by spectral characteristics. The regression coefficient R2 is 0,98 ; the sum of squared errors is 183,6 ; root mean square error is 3,194 . Can be concluded that the titratable acidity can be predicted by spectral characteristics at $98 \%$ accuracy, but high levels of errors.

IRTIIE Vol. 4, No. 1, 2016 ISSN 1314-8788 (print), ISSN 1314-8796 (online), doi: 10.15547/artte.2016.01.005 
Table 9. Analysis of the results for a common error in data classification

\begin{tabular}{|c|c|c|c|c|c|c|c|}
\hline \multicolumn{8}{|c|}{ Anova: Two-Factor Without Replication } \\
\hline SUMMARY & Count & \multicolumn{2}{|c|}{ Sum } & \multicolumn{2}{|c|}{ Average } & \multicolumn{2}{|c|}{ Variance } \\
\hline DA & 3 & & 63,25 & \multicolumn{2}{|c|}{21,08} & \multicolumn{2}{|r|}{515,15} \\
\hline KNN & 3 & & 64,50 & \multicolumn{2}{|c|}{21,50} & \multicolumn{2}{|r|}{133,56} \\
\hline SVM & 3 & & 38,25 & \multicolumn{2}{|r|}{12,75} & \multicolumn{2}{|r|}{315,44} \\
\hline Raw & 3 & & 109,75 & \multicolumn{2}{|c|}{36,58} & \multicolumn{2}{|r|}{84,90} \\
\hline$A R$ & 3 & & 40,25 & \multicolumn{2}{|r|}{13,42} & \multicolumn{2}{|r|}{155,90} \\
\hline PC & 3 & & 16,00 & \multicolumn{2}{|r|}{5,33} & \multicolumn{2}{|r|}{7,15} \\
\hline \multicolumn{8}{|c|}{ ANOVA } \\
\hline \multicolumn{2}{|c|}{ Source of Variation } & SS & $d f$ & MS & $\boldsymbol{F}$ & P-value & F crit \\
\hline \multicolumn{2}{|l|}{ Rows } & 146,18 & 2,00 & 73,09 & 0,84 & 0,50 & 6,94 \\
\hline \multicolumn{2}{|l|}{ Columns } & 1578,60 & 2,00 & 789,30 & 9,03 & 0,03 & 6,94 \\
\hline \multicolumn{2}{|l|}{ Error } & 349,69 & 4,00 & 87,42 & & & \\
\hline \multicolumn{2}{|l|}{ Total } & 2074,47 & 8,00 & & & & \\
\hline
\end{tabular}

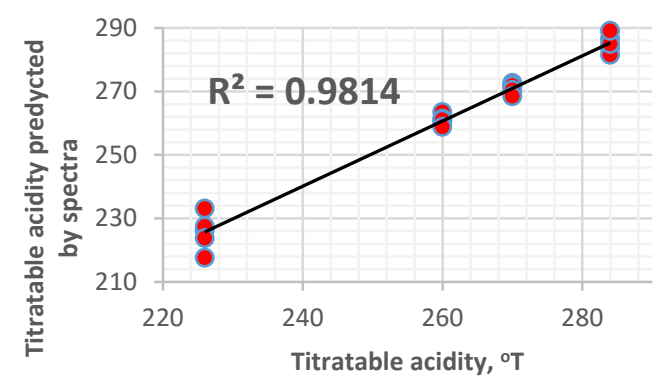

a) by PLSR

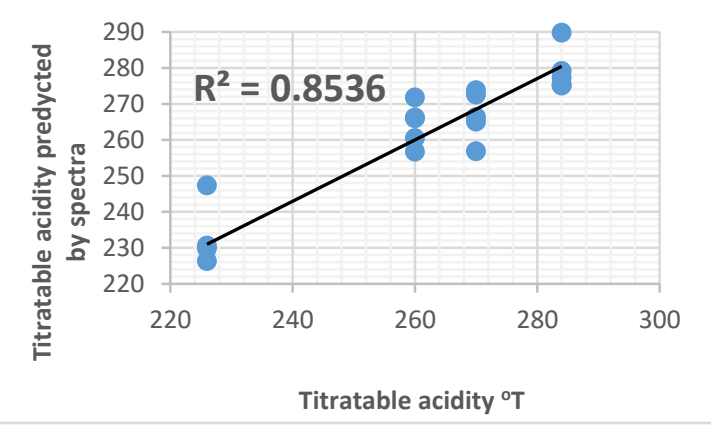

b) by PCR

Figure 12. Predicting the titratable acidity by spectral characteristics

Predicting the titratable acidity by principal components regression. Figure $12 \mathrm{~b}$ presents the results of prediction of titratable acidity from spectral characteristics by principal components regression. The regression coefficient $R^{2}$ is 0,85 ; the sum of squared errors is 1145; root mean square error is 7,974. Can be concluded that the titratable acidity can be predicted by spectral characteristics at $85 \%$ accuracy, but high levels of errors.

\section{CONCLUSION}

This report provides an overview of current research related to the quality and safety of dairy products. From the analysis of publishing activity in this field is found that the yellow cheese is the main subject of study because it is one of the commonly consumed dairy product along with cheese curd and yogurt. Moreover, this product is a favorable environment for the development of hostile microorganisms.

A review was made of the methods and technical equipment for assessing the quality and safety of yellow cheese in which it is established that are suitable for the purpose contactless methods because the measurement with contactless sensors does not affect the composition and structure of the product.

IRTIIE Vol. 4, No. 1, 2016 ISSN 1314-8788 (print), ISSN 1314-8796 (online), doi: 10.15547/artte.2016.01.005 


\section{ART'TE

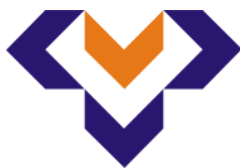 \\ Ipplied Resseirlches in Technics, Technologies and Bductation \\ Journal of the Faculty of Technics and Technologies, Trakia University https://sites.google.com/a/trakia-uni.bg/artte/}

From contactless methods with small error values up to $2 \%$, in determining the content of substances harmful to health in dairy products and the ability to predict the physicochemical parameters with accuracy more than $97 \%$ have proven optical methods.

In recent years, optical methods of research have proved the spectral and hyperspectral analysis. From these methods is selected spectral analysis because it is easy to use method and does not require special preparation of measuring equipment.

An assessment is made of the possibilities for separating objects areas on the surface of yellow cheese during storage in conditions not regulated from specified by the manufacturer using the three most commonly used in the analysis of food products classifiers - SVM, KNN and DA. The work of these classifiers was evaluated by the common error of classification. From this analysis it is found that the direct use of spectral characteristics the classification common error is over $10 \%$. Suitable to use are principal components for the representation of spectral characteristics and classification because the common error of classification is up to $5 \%$.

For classification are suitable the discriminant analysis (DA) using nonlinear discriminant function and support vector machines (SVM) with the use of principal components, because the processing time is up to $5 \mathrm{~s}$.

The use of KNN classification method is impractical because the total error of the classification in it, irrespective of the method for representing the spectral data is greater than $10 \%$, while in comparison with the other two classifier processing time in this classifier is shortest.

\section{LITERATURE}

[1] Aljaafreh Ahmad, and Ralf Lucklum. On-line Monitoring of Yogurt Fermentation Using Ultrasonic Characteristics. At Vienna, Austria, Volume: 1. ISBN:978-1-61804-285-9.

[2] D'huysa K., J. Claesb, B. D. Ketelaerea. Rapid, Non-contact Viscosity Measurements of Stirred Yoghurt with the Foodtexture Puff Device. InsideFood Symposium, 9-12 April (2013), Leuven, Belgium.

[3] Daskalov P., V. Mancheva, Ts. Draganova, R. Tsonev. An Approach for Fusarium Infected Corn Kernels Recognition Using Linear Discrete Models, Agricultural Science and Technology, Vol. 2, No 2, pp. 90-95, 2010.

[4] Development Trends of Key Sub-sectors of Dairy Farming Project Modeling of the Baseline Indicators (April 2014), http://archpbg.com/attachments/article/294/\%D0\%91\%D0\%98-2.pdf. (available on 26.04.2015).

[5] Dimitrova A. Analysis of SEM Images of Magnetically Threated Ceramic Materials. Applied Scientific Journal, Innovation and Entrepreneurship, Vol. 4, No 1, 2016, ISSN 1314-9253, pp.35-43.

[6] Ellis D. I., V. L. Brewster, W. B. Dunn, J. W. Allwood, A. P. Golovanovc, R. Goodacreab. Fingerprinting Food: Current Technologies for the Detection of Food Adulteration and Contamination. Chem. Soc. Rev., Vol. 41, 2012, pp. 5706-5727.

[7] Fayolle Ph., D. Picque, G. Corrieu. On-line Monitoring of Fermentation Processes by a New Remote Dispersive Middle-infrared Spectrometer. Food Control 11.4 (2000): 291296.

[8] Georgieva A., I. Taneva, I. Milkov. Researches on the Possibilities for Obtaining of Foodstuffs with the Participation of Flavio Roza Sinensis Hibiscus and in Combination with Some Herbs Having Healing Properties. Trakia Journal of Sciences, Vol.1, No.3, 2003, pp.49-52.

[9] Google Scholar, https://scholar.google.com/. (available on 12.02.2016).

IRTIIE Vol. 4, No. 1, 2016 ISSN 1314-8788 (print), ISSN 1314-8796 (online), doi: 10.15547/artte.2016.01.005 
[10] Jarén C., M. Gago, S. Arazuri, A. López, N. Arias, A. C. Santos, P. C. Correa. The Potential of Near Infrared Spectroscopy as a Method of Determination of the Fat Content in Yogurt. (2011).

[11] Manley M. Near-infrared Spectroscopy and Hyperspectral Imaging: Non-destructive Analysis of Biological Materials. Chem. Soc. Rev., Vol. 43, 2014, pp. 8200-8214.

[12] Meng R., J. Zhou, X. Ye, D. Liu. On-line Monitoring of Yogurt Fermentation Using Acoustic Impedance Method. Applied Mechanics and Materials, 101-102 (2012): 737742.

[13] Mladenov M. I. Analysis and Evaluation of Grain Quality. Rousse, 2011, ISBN 978-954712-530-8. (in Bulgarian).

[14] Mladenov M. I., E. D. Dimitrov, M. P. Dejanov, S. M. Penchev. Hyperspectral Imaging System Based on „Point Scan” Spectrophotometer. Proceedings of International Conference "Automatics and Informatics '2014", Sofia, Bulgaria, 2014, I-39-I-42.

[15] Mucchetti G., M. Gatti, E. Neviani. Electrical Conductivity Changes in Milk Caused by Acidification: Determining fFactors. Journal of Dairy Science, 77.4 (1994): 940-944.

[16] Mwenze P. M. Functional Properties of Goats' Milk: A Review. Research Journal of Agriculture and Environmental Management, Vol. 4 (9), September, 2015, ISSN 23158719, pp. 343-349.

[17] Nachev V., T. Titova, Ch. Damyanov, K. Velcheva. Selection of Features in Forming the Feature Space in Classification Tasks. International Conference Automatics and Informatics '13, I-267-I-270, 3-7.10.2013, Sofia. (in Bulgarian).

[18] Nielsen O. Development of Broadband Multispectral Imaging for Analysis of Dairy Products. Photonex 2010 Conference on Spectral Imaging, 3th November (2010).

[19] Palmer P., S. Webber, K. Ferguson. On the Suitability of Portable X-ray Fluorescence Analyzers for Rapid Screening of Toxic Elements. Laboratory Information Bulletin, LIB \# 4376, (2006).

[20] Paquet J. Electrical Conductivity as a Tool for Analysing Fermentation Processes for Production of Cheese Starters. International Dairy Journal, 10.5 (2000): 391-399.

[21] Peris M., L. Escuder-Gilabert. On-line Monitoring of Food Fermentation Processes Using Electronic Noses and Ectronic Tongues: A review. Analytica Chimica Acta, 804 (2013): 29-36.

[22] Picque D., G. Corrieu. New Instrument for On-line Viscosity Measurement of Fermentation Media. Biotechnology and Bioengineering, 31.1 (1988): 19-23.

[23] Robertson I. Rapid Testing for Adulteration of Yogurt Candy using Near-infrared Spectroscopy and Adulterant Screen. PerkinEImer, Inc., Shelton, CT, Application Brief (2014)

[24] Science Direct, http://www.sciencedirect.com/. (available on 15.03.2016).

[25] Sergi F. S. NIR Techniques and Chemometric Data Analysis Applied to Food Adulteration Detection. Thesis in Enabling Technologies for the Food and Bioprocessing Industry, October, (2015).

[26] Shao Y., Y. He, S. Feng. Measurement of Yogurt Internal Quality through Using Vis/NIR Spectroscopy. Food Research International, 40 (2007), pp.835-841.

[27] Soukoulis C., et al. Industrial Yogurt Manufacture: Monitoring of Fermentation Process and Improvement of Final Product Quality. Journal of Dairy Science, 90.6 (2007): 26412654.

[28] Supavititpatana P., T. I. Wirjantoro, P. Raviyan. Characteristics and Shelf-Life of Corn Milk Yogurt. CMU. J. Nat. Sci. (2010) Vol. 9 (1), pp.133-149.

[29] Support Vector Machines, http://www.mathworks.com/help/stats/support-vectormachines-svm.html. (available on 08.06.2015).

IRTIIE Vol. 4, No. 1, 2016 ISSN 1314-8788 (print), ISSN 1314-8796 (online), doi: 10.15547/artte.2016.01.005 


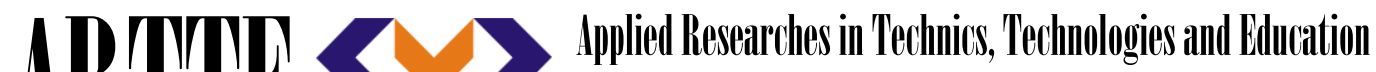 Journal of the Faculty of Technics and Technologies, Trakia University https://sites.google.com/a/trakia-uni.bg/artte/}

[30] Svendsen C., Skov, T. and van den Berg, F. W. J. (2015). Monitoring Fermentation Processes Using In-process Measurements of Different Orders. J. Chem. Technol. Biotechnol., 90: 244-254. doi:10.1002/jctb.4483.

[31] Van Steenkiste F., Baert K, Debruyker D, et al. A Microsensor Array for Biochemical Sensing. Sensors Actuators B - Chem 44:409-412 (1997).

[32] Veleva-Doneva P., Ts. Draganova, St. Atanasova, R. Tsenkova, 2010. Detection of Bacterial Contamination in Milk Using NIR Spectroscopy and Two Classification Methods - SIMCA and Neuro - Fuzzy Classifier. AGRICONTROL 2010, IFAC International Conference, Kyoto, Japan.

[33] Vyawahare A., Jayaraj-Rao K., Pagote C.N. Computer Vision System for Colour Measurement - Fundamentals and Applications in Food Industry: A Review. Journal of Food and Dairy Technology, Vol.1, Iss. 2, October-December 2013, ISSN:2321-6204, pp. 22-31.

[34] Wallace T., M. M. Giusti. Determination of Color, Pigment, and Phenolic Stability of NonAcylated Anthocyanins from Berberis boliviana L. in Yogurt Systems. The Ohio State University, (2015).

[35] Xu L.,S-M. Yan, C-B. Cai, Z-Ji. Wang, X-P. Yu. The Feasibility of Using Near-Infrared Spectroscopy and Chemometrics for Untargeted Detection of Protein Adulteration in Yogurt: Removing Unwanted Variations in Pure Yogurt. Journal of Analytical Methods in Chemistry, Volume 2013, Article ID 201873, (2013).

[36] Christensena J., E. Miquel Beckerb, C.S. Frederiksenb. Fluorescence Spectroscopy and PARAFAC in the Analysis of Yogurt. Chemometrics and Intelligent Laboratory Systems 75 (2005), pp. 201-208.

[37] He Y., S. Feng, X. Deng, X. Li. Study on Lossless Discrimination of Varieties of Yogurt Using the Visible/NIR-spectroscopy. Food Research International, 39 (2006), pp.645650.

IRTIIE Vol. 4, No. 1, 2016 ISSN 1314-8788 (print), ISSN 1314-8796 (online), doi: 10.15547/artte.2016.01.005 